
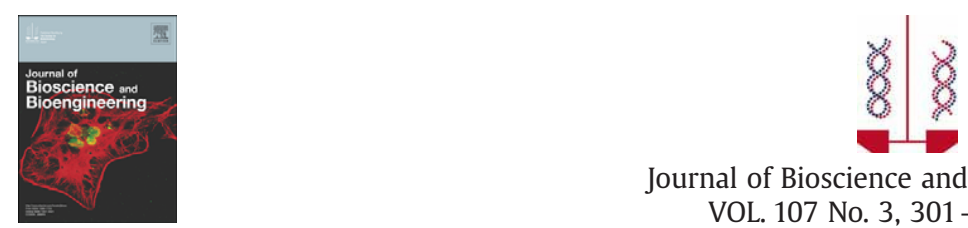

Journal of Bioscience and Bioengineering

VOL. 107 No. 3, $301-306,2009$

www.elsevier.com/locate/jbiosc

\title{
Evidence of genotype dependency within Agrobacterium tumefaciens in relation to the integration of vector backbone sequence in transgenic Phytophthora infestans-tolerant potato
}

\author{
Carloalberto Petti, ${ }^{1,2, \dagger}$ Toni Wendt, ${ }^{1}$ Conor Meade, ${ }^{2}$ and Ewen Mullins ${ }^{1, *}$ \\ Teagasc, Biotechnology Unit, Crops Research Centre, Oak Park, Carlow, Co. Carlow, Ireland ${ }^{1}$ and \\ Department of Biology, Institute of Bioengineering and Agroecology, National University of Ireland, Maynooth, Co. Kildare, Ireland ${ }^{2}$
}

Received 4 August 2008; accepted 6 November 2008

\begin{abstract}
In this study the effect of Agrobacterium tumefaciens genotype of two strains AGL1 and LBA4404 was investigated in regard to the propensity for backbone integration during the transformation of potato for blight tolerance conferred by the resistant to blight $(R B)$ gene carried by the vector pCLD04541. A PCR based walking approach was employed to identify left and right backbone sequences as well as for selected genes carried on the plasmid backbone. It was found that adjacent to the left border insertion site, the integration of backbone sequence was greater for AGL1 than for LBA4404; however, the opposite was observed with regards to the right border T-DNA junction. Considering both T-DNA borders LBA4404 was found to have a two fold greater integration potential for backbone than the AGL1. The possibility of only backbone integration in T-DNA negative plants was also investigated with the average rate of integration between the two strains calculated at $4.2 \%$ with LBA4404 recording a three fold greater occurrence of backbone integration than AGL1. In summary, evidence of Agrobacterium genotype dependency showed that LBA4404 has greater potential to integrate non-T-DNA vector sequence than AGL1 and this should be taken into account when utilising the listed $A$. tumefaciens genotypes in generating transgenic potato. Additionally, the application of a PCR and primer walking system proved to be reliable and allows for fine detailed studies of backbone sequence integration of transgenic plant.
\end{abstract}

(c) 2008, The Society for Biotechnology, Japan. All rights reserved.

[Key words: Agrobacterium; Transformation; Potato; Transgenic; RB; Backbone integration]

Agrobacterium tumefaciens-mediated transformation (ATMT) is the main process employed for plant transformation. Established initially on dicot species (1-4), it has been extended to monocots with an ever increasing efficiency (5-10). The ATMT of plant species occurs through the delivery and integration of the T-DNA containing a gene(s) of interest, in to the target cell/tissue. T-DNA transfer is unspecific with regard to its insertion site within the host genome; however studies have shown a preference for T-DNA integration to occur in highly transcribed regions (11-13). The right and left border repeat sequences of the T-DNA are required for its integration, which requires the T-DNA to be cut precisely at the right border. Integration can also result in the nicking of the left border T-DNA sequence which can occur in an imprecise fashion leading to the delivery of non-T-DNA sequences from the vector backbone (14-16). Integration of a transgene into a plant genome will have intended effects, which are those that are targeted to occur from the introduction of the gene(s) (17). On the contrary, the erroneous integration of vector backbone sequence might have

\footnotetext{
* Corresponding author. Tel./fax: +353 0599170298/2343.

E-mail address: Ewen.Mullins@Teagasc.ie (E. Mullins).

Present address: University College Dublin, School of Biology and Environmental Science, Molecular Plant-Pathogen Interaction Group, Science West, Belfield, Dublin, Ireland.
}

"unpredictable and unintended effects" (17). Specifically, the integration of backbone sequence might participate in the silencing of endogenous/non-endogenous gene(s) $(18,19)$. Additionally, it has been suggested that it could facilitate the horizontal transfer of genes between a transgenic plant and a microorganism based on the availability of DNA microhomology $(20,21)$.

Evidence of backbone integration post-ATMT has been accumulated from several plant species: tobacco $(14)$, rice $(22,23)$ Arabidopsis (24) strawberry (25) cherry rootstock (26) and barley (27). In regards to potato, the fourth most important crop worldwide (28) and one of the first crops to be transformed $(29,30)$, two studies $(31,32)$ have been published one of which, investigated the application of in situ hybridization of extended DNA fibres to evaluate the integration patterns of T-DNA and backbone sequence (32). In general, only small populations of transgenic plants have been analysed and to date, no study has examined the effect of bacterial genotype on the propensity for backbone integration. The aim of this study was therefore to investigate the influence of bacterial genotype on the propensity to deliver non-T-DNA (backbone) sequence in a large population of putative transgenic potato plants $(n=327)$. This was achieved using two A. tumefaciens strains (AGL1 and LBA4404) both of which were equipped with the vector pCLDO4541 to confer resistance to Phytophthora infestans through expression of the $R B$ gene $(33,34)$; 
furthermore described as the resistant to blight $(\operatorname{Res} B l)$ gene to avoid confusion with the T-DNA right border (RB). Furthermore, we investigated the presence or absence of backbone sequences in $\mathrm{T}$ DNA negative plants known as escapes.

\section{MATERIALS AND METHODS}

Plant and vector materials The plant material used in this investigation was Solanum tuberosum L., cv. Désireé and consisted of internodal explants taken from sterile in vitro plantlets of 4 to 6 weeks old which, according to their length, were cut into segments of circa $5 \mathrm{~mm}$. For this study, an average of 250 stem fragments per treatment was employed for each ATMT. The vector used was pCDLO4541 (35), (Accession number: AF184978) which was kindly provided by Dr. Jiming Jang, University of Wisconsin, Madison, USA. This vector (27.6 kb), contains the ResBl gene ( $8.6 \mathrm{~kb})$, which confers increased resistance to $P$. infestans $(33,34)$. Transgenic plant selection was assessed through resistance to kanamycin $(50 \mu \mathrm{g} / \mathrm{ml})$, as conferred by the nptII gene. Bacterial selection was conferred by the Tet gene located on the pCLD04541 backbone. The plasmid was introduced into A. tumefaciens strains AGL1 (36) and LBA4404 (37) by the freeze-thaw method (38). Regeneration, transformation and selection of Désireé explants were carried out as in Petti et al. (unpublished data). Briefly, on following bacterial exposure $\left(\mathrm{OD}_{600}=1.0\right)$ of the explants, they were transferred to MS media and co-cultivated for 2/3 day. A. tumefaciens overgrowth was washed off (MS medium plus cefotaxime-500 $\mu \mathrm{g} / \mathrm{ml}$ ) and blot-dried samples were transferred to callus inducing media consisting of MS basal salts $(4.414 \mu \mathrm{g} / \mathrm{ml}$, Apollo Scientific, Stockport, Cheshire, UK), ZR ( $0.8 \mu \mathrm{g} / \mathrm{ml}$; Apollo Scientific, UK), thiamine-HCl (10 $\mu \mathrm{g} / \mathrm{ml}$; Sigma, St. Louis, MO, USA), pyridime-HCl ( $1 \mu \mathrm{g} / \mathrm{ml}$; Sigma), nicotinic acid ( $1 \mu \mathrm{g} / \mathrm{ml}$; Sigma), NAA (0.3 $\mu \mathrm{g} / \mathrm{ml}$; Sigma), BAP (2.25 $\mu \mathrm{g} / \mathrm{ml}$; Sigma ) and 2, 4-D (0.05 $\mu \mathrm{g} / \mathrm{ml}$; Sigma), sucrose (3\%; Sigma) and agar technical 3 (0.6\%, Oxoid, Basingstroke, Hampshire, UK), cefotaxime (500 $\mu \mathrm{g} / \mathrm{ml}$; Apollo Scientific) and the plant selective antibiotic, kanamycin $(50 \mu \mathrm{g} / \mathrm{ml}$; Apollo Scientific). Fragments were sub-cultured every 2 weeks on to fresh media. Each treated fragment was evaluated for the formation of independent calli (callus formed in noncontiguous areas) indicating putative independent transformation events; these were transferred to shoot inducing media (MS basal salts $4.414 \mu \mathrm{g} / \mathrm{ml}), \mathrm{ZR}(0.8 \mu \mathrm{g} / \mathrm{ml}$; Apollo Scientific), thiamine- $\mathrm{HCl}(10 \mu \mathrm{g} / \mathrm{ml})$, pyridime- $\mathrm{HCl}(1 \mu \mathrm{g} / \mathrm{ml})$, nicotinic acid $(1 \mu \mathrm{g} / \mathrm{ml})$, gibberellic acid $\left(\mathrm{GA}_{3}, 0.8 \mu \mathrm{g} / \mathrm{ml}\right.$; Sigma) sucrose (3\%) and agar technical 3 (0.6\%; Oxoid) till shoot formation. From each independent event, a single shoot was transferred to root inducing media (RIM), as for SIM without $\mathrm{GA}_{3}$ supplemented with indoleacetic acid (IAA, $0.1 \mu \mathrm{g} / \mathrm{ml}$; Sigma) at full kanamycin selection $(100 \mu \mathrm{g} / \mathrm{ml})$ and incubated at $22^{\circ} \mathrm{C}$ for $16 / 8 \mathrm{~h}$ day length. For DNA extraction, the growing shoots were excised near the base and put into a $2.2 \mathrm{ml}$ eppendorf and a glass bead ( $3 \mathrm{~mm}$ diameter; Qiagen, Crawley, West Sussex, UK) added. The samples were pre-frozen at $-80^{\circ} \mathrm{C}$ for $1-2 \mathrm{~h}$ and freezedried for 24-48 h. The plant material was disrupted in a mixer mill (Retsch $\mathrm{GmbH}$, MM400, Haan, Germany) and the DNA extracted via a modified CTAB method to accommodate the $2.2 \mathrm{ml}$ sample size.

\section{Primer design}

Verification of transgenic lines The molecular diagnosis of the putative ResBl lines was completed through single and multiplex PCR. Single PCR evaluation was completed using ResBl gene-specific primers (ResBl-F, ResBl-R: Table 1), which were designed according to the principles of Mismatch Amplification Mutation Assay (MAMA) PCR and described elsewhere (39). Multiplex PCR screening targeted: ResBl-nptII and 35S-nptII which amplified 812 bp and $535 \mathrm{bp}$, and 515/535 bp and $1070 \mathrm{bp}$ fragments respectively (Fig. 2). Primer sequences required for the detection of the nptII ResBl genes and $35 \mathrm{~S}$ promoter are given in Table 1 . The PCR conditions for the ResBl primers and for the multiplex PCRs were: first cycle $96^{\circ} \mathrm{C}$ for $6 \mathrm{~min}, 94^{\circ} \mathrm{C}$ for $15 \mathrm{~s}, 57^{\circ} \mathrm{C}$ for $30 \mathrm{~s}, 68^{\circ} \mathrm{C} 1 \mathrm{~min}$, 35 additional cycles and 5 min final extension at $72^{\circ} \mathrm{C}$. The PCR was carried out with $20 \mathrm{ng}$ of DNA, $200 \mu \mathrm{M}$ of dNTP's, $10 \mathrm{pM}$ of primers and 0.20 units/ $\mu \mathrm{l}$ of Taq polymerase (NEB, Wilbury Way, Hitchin, Herts, UK) made up to a $20 \mu \mathrm{l}$ reaction with $1 \times$ buffer and PCR-grade water.

Synchronous and asynchronous backbone analysis Synchronous backbone analysis (SBA hereafter) aims to determine the presence/absence of pCLDO4541 backbone sequences, be it adjacent to the right and/or left T-DNA border, in the ResBl positive plants. The asynchronous analysis investigated the possibility that T-DNA negative lines contained pCDLO4541 backbone integrated within their genome. For both analyses, a PCR based primer walking approach was utilised. A single forward primer was designed within the T-DNA and upstream of the left border (Accession number: AY234326) while the reverse primers (12 sets) were designed downstream of the left border and out on the plasmid backbone with an incremental size from $150 \mathrm{bp}$ to $621 \mathrm{bp}$ (Fig. 1). The primer sequences and the expected products are given in Table 1 . Furthermore, two more downstream primers (IN1 and IN2) were designed at $730 \mathrm{bp}$ (IN1) and at 1840 bp from the left border (IN2, Table 1). The primers (lb 1-12, IN1 and IN2) were designed to have a similar melting temperature and a generic program was adequate to amplify each of the above sets using the vector DNA as a control template (illustrated in Fig. 3). PCR conditions were: cycle $1,96{ }^{\circ} \mathrm{C}$, for $5 \mathrm{~min} ; 96^{\circ} \mathrm{C}$ for $50 \mathrm{~s}, 54{ }^{\circ} \mathrm{C}$ for $35 \mathrm{~s}, 72^{\circ} \mathrm{C}$ for $50 \mathrm{~s}$, for 30 cycles and a final extension of $5 \mathrm{~min}$ at $72{ }^{\circ} \mathrm{C}$. PCR reaction carried out as previously described. To analyse the frequency of integration of the backbone sequences on the right border, only two primers were designed, rb1 and rb2 (Fig. 1 and Table 1). The forward primer was internal to the T-DNA sequences and located at $271 \mathrm{bp}$ upstream of the position of the right border (AY456904) while two external
TABLE 1. Sequences of primers adopted for the synchronous and asynchronous backbone analysis

\begin{tabular}{|c|c|c|}
\hline Primer & Sequence & Size product (bp) \\
\hline lb1-12-F & 5'-ATAATAACGCTGCGGACATCT & 150 \\
\hline lb1-R & 5'-GGCGGCAGGATATATTCAA & \\
\hline lb2-R & 5'-GCGTAGAAACCAACATGCAA & 195 \\
\hline lb3-R & 5'-GCCTAACCGGCTCAGTTCTG & 204 \\
\hline lb4-R & 5'-GCACATGGCTCAGTTCTCAA & 246 \\
\hline lb5-R & 5'-CCGTCGCTCACCGTGTT & 274 \\
\hline lb6-R & 5'-AGTCCCATGTGGATCACTCC & 300 \\
\hline lb7-R & 5'-CGGATCCGACGGATGATGTT & 324 \\
\hline lb8-R & 5'-GTCGGCTTGATCTCACCGA & 362 \\
\hline lb9-R & 5'-ATCGTGTTGCGCGCCTG & 387 \\
\hline lb10-R & 5'-CGTCGGCTCGATTGTACCTG & 424 \\
\hline lb11-R & 5'-TAGCTTGCTTGGTCGTTCCG & 454 \\
\hline lb12-R & 5'-CGAAATCCTTGGGCCTCCAC & 621 \\
\hline rb-F & 5'-TTGCCTTTTCTTATCGACCA & 379 \\
\hline rb-R1 & 5'-TCGGCAGTTCATCAGGGCTA & \\
\hline rb-R2 & 5'-AATATGCGTCCCTTTGGAGA & 539 \\
\hline IN1-F & 5'-AGCAGTACCAGCAGGAATGG & 330 \\
\hline IN1-R & 5'-TTGGTTGAACATAGCGGTGA & \\
\hline IN2-F & 5'-CAGGGCATCAAGAAGATGGT & 485 \\
\hline IN2-R & 5'-GTCCAGGTCCAGCTCGATAG & \\
\hline Oriv-F & 5'-GCAGCCCTGGTTAAAAACAA & 449 \\
\hline OriV-R & 5'-GATACCTCGCGGAAAACTTG & \\
\hline Tra-F & 5'-GCTGATCCTGCATACCATCA & 359 \\
\hline Tra-R & 5'-ATAACGAGGCCCACACCAC & \\
\hline Tet-F & 5'-ATGCTGGCGGAGAATCATAC & 452 \\
\hline Tet-R & 5'-TCAACGTTCCTGACAACGAG & \\
\hline TrfA-F & 5'-ATCGACACGCGAGGAACTAT & 409 \\
\hline TrfA-R & 5'-CCTGGCAAAGCTCGTAGAAC & \\
\hline VirD2-F & 5'-GCAGAGCGACCAATCACATA & 360 \\
\hline VirD2-R & 5'-GGCTTCAGCGACATAGGAAG & \\
\hline At-F & 5'-TGCTACСССТTCATCAAACC & 375 \\
\hline At-R & 5'-GTTGTTTGTCCGCCTTGTTT & \\
\hline ResBl-F & 5'-CATCTTGAGAGAGTGAAGAATGATCT & 812 \\
\hline ResBl-R & 5'-CTAGTGCGCAACACAATTGAA & \\
\hline NPTII-F & 5'-GATGTAGGAGGGCGTGGATA & 535 \\
\hline NPTII-R & 5'-GATGTTGGCGACCTCGTATT & \\
\hline $35 \mathrm{~S}-\mathrm{F}$ & 5'-AAACCTCCTCGGATTCCATT & 515 \\
\hline $35 S-R$ & 5'-GCTCAACACATGAGGGAAAC & \\
\hline
\end{tabular}

(reverse primers) to the T-DNA and on the backbone sequence were designed at $106 \mathrm{bp}$ and 268 bp downstream the right border (Fig. 1). PCR conditions and reactions were as for the left border analysis and were previously described.

For the asynchronous backbone analysis (AsBA hereafter), the DNA of T-DNA negative lines was checked for the presence of 4 backbone genes. These genes were $\operatorname{Trf} A$ (AY204478), Tet (AY204478), Tra and OriV (AY204478) and their primer sequences and the expected amplicon sizes are reported in Table 1. The PCR conditions for these sets of primers were $95{ }^{\circ} \mathrm{C}$ for $10 \mathrm{~min}, 94^{\circ} \mathrm{C}$ for $1 \mathrm{~min} 60^{\circ} \mathrm{C}$ for $30 \mathrm{~s},-1{ }^{\circ} \mathrm{C}$ per cycle, $72{ }^{\circ} \mathrm{C}$ for 1 min, nine cycles with an additional 24 cycles at $94^{\circ} \mathrm{C}$ for $30 \mathrm{~s}, 55^{\circ} \mathrm{C}$ for $30 \mathrm{~s}, 72^{\circ} \mathrm{C}$ for $30 \mathrm{~s}$ and a final extension of $10 \mathrm{~min}$ at $72^{\circ} \mathrm{C}$. The PCR reaction was carried out as for the SBA test previously described. Two distinct sets of primers for A. tumefaciens were employed; the first designed specifically for the detection of $A$. tumefaciens chromosomal sequences (http://www.agrobacterium.org, accession number: AE007870) while the second set was based on sequences for the A. tumefaciens virD2 gene (AF242881).

Southern analysis was also completed on the 3 AsBA positive lines using a PCR generated amplicon of the Tet gene from the vector PCLD04541 as a probe. This was not possible on 2 LBA4404 lines due to their accidental destruction in the glasshouse. The PCR amplicon was gel purified (QIAquick, Qiagen), following the manufacturers indications and utilised in a random priming reaction using a direct alkaline phosphatase reaction (Alkphos, Amersham, UK) following the manufacturers instructions. Signal was generated by the application on the membranes of the enhanced chemifluorescence (ECF) substrate and a molecular scanner (Thyphoon T9410, Amersham, Little Chalfont, Buckinghamshire, UK) was employed to record the fluorescent signal.

\section{RESULTS}

Genotypes of $A$. tumefaciens influenced transformation rate An initial 481 potato stem explants were exposed to $A$. tumefaciens; 254 treated with AGL1 and 227 with LBA4404. Both strains harboured the vector pCLD04541 containing the ResBl gene, to enhance tolerance to $P$. infestans $(33,34)$. A total of 455 independent putative transgenic calli formed on the treated fragments (Table 2) from which 327 lines were regenerated with 209 PCR-positive for the 


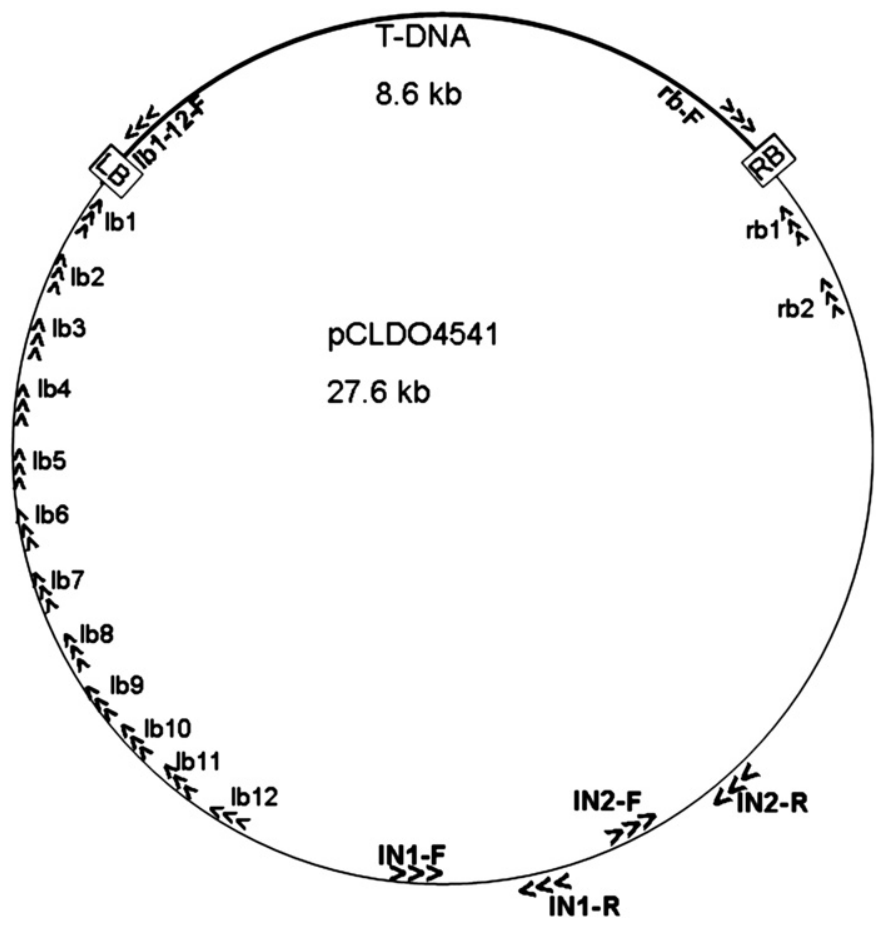

FIG. 1. Schematic representation detailing location of diagnostic primers (lb1-lb12; lb112-F; IN1, IN2-F, IN1, IN2-R; rb-F, rb1 and rb2) for pCDLO4541.

ResBl transgene (as illustrated in Fig. 2), equating to a transformation rate of 43.4\% (209/481) with respect to the overall fragments exposed. However, with respect to the $A$. tumefaciens strains employed the transformation rate was $47.6 \%$ for AGL1 and $38.7 \%$ for LBA4404. The TDNA negative lines, which were PCR-negative to all the T-DNA genes: ResBl, NPTII and 35S promoter, accounted for a total of 118 plants with 79 derived from the AGL1 treatment and 39 from LBA4404.

Synchronous backbone analysis (SBA): evidence for $A$. tumefaciens genotype dependency A chromosome walking approach was employed for the SBA (Fig. 3) to determine the extent of backbonesequence integration at either the left or right border of the T-DNA insertion site. Prior to proceeding with the SBA evaluation, the $209 \mathrm{~T}-$ DNA-ResBl positive lines were examined for the presence of $A$. tumefaciens chromosome specific sequence and for the Ti plasmidcarried virD2 gene sequences. In $10 \%$ of the transgenic lines $(n=20$, data not shown) we found evidence of such sequences and those lines were eliminated from the investigation. Of the remaining 189 lines (109 AGL1-derived and 80 LBA4404-derived), which were initially analysed at the left border only of the insertion site, we found that with respect to the Désiree transgenic lines 6.4\% (7/109) of the AGL1-derived ResBl lines contained backbone sequence whereas only $3.8 \%$ (3/80; line $6-2,7-2$, 8-2) tested positive within the LBA4404-derived population (Table 3). The majority of these AGL1 and LBA4404 derived lines tested positive for all the 12 left border primers tested with an integrated non-T-DNA
(A)

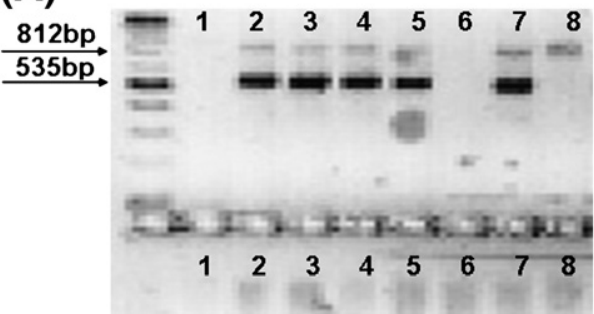

(B)

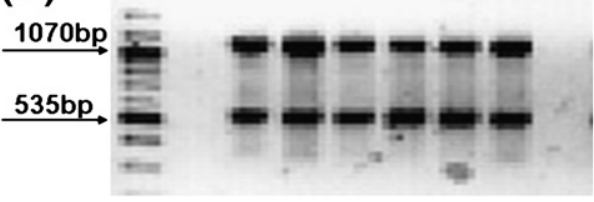

FIG. 2. Representative PCR screening of ResBl lines. (A) Multiplex PCR to identify ResBl and the nptII gene from 5 transgenic lines. (B) The same lines tested using a multiplex PCR for the 35S and for the nptII gene. 6: blank lane, 7: untreated plant DNA, 8: pCDLO4541 DNA.

sequence of $621 \mathrm{bp}$. Three of the 8 AGL1 lines tested positive for a lower number of primer sets. More specifically 2 lines (2-1 and 3-1) for 11 primer sets with 454 bp backbone sequence integrated and 1 line (5-1) for 10 primer sets corresponding to $424 \mathrm{bp}$ of backbone sequence integrated. An analogous pattern was also reported for the LBA4404derived population with 2 out of 8 (line $4-2$ and 5-2) being positive to 11 sets of primers and 454 bp of backbone sequence integrated. Furthermore, we found evidence, for each of the AGL1 and LBA4404derived populations, of backbone sequence amplified up to $1800 \mathrm{bp}$ downstream (with IN1 and IN2 primer pairs) from the left border. This represented $6.4 \%(7 / 109)$ and $10 \%$ (8/80) of the AGL1 and the LBA4404 treated populations respectively. Considering that the IN2 was designed 1800 bp downstream of the left border and the resulting amplicon was an additional $485 \mathrm{bp}$, it implies that for these specific lines at least $2.2 \mathrm{~kb}$ of backbone sequence was integrated into the host chromatin.

The presence of non-T-DNA sequences, solely on the right border, was detected only in 1 case (line 9-1) for the AGL1-derived lines (0.90\%; $1 / 109)$ but in 4 LBA4404 lines ( $5 \%$, line $9-2,10-2,11-2$ and $12-2$, Table 3). Moreover, an AGL1-derived line which was left-borderpositive was also found to be right-border-positive whereas for the LBA4404-derived ResBl lines 5 tested positive for the left and right border sequences (Table 3 ).

The overall frequency of integration for backbone sequences (either left or right border) was, with respect to the AGL1 recovered ResBl transgenic lines, calculated at 8.2\% (9/109) whereas with regards to the LBA4404 lines, it equated to $15 \%(12 / 80)$.

Asynchronous backbone analysis (AsBA): backbone transgenesis of potato plants A total of 118 Désireé lines were T-DNA negative (PCR-negative to ResBl, nptII and 35S promoter) following treatment with either A. tumefaciens genotypes (Table 2). When tested none of this population possessed either A. tumefaciens chromosomal DNA

TABLE 2. Details of the transformation experiments on Désireé fragments by A. tumefaciens strain AGL1 and LBA4404 carrying the vector pCLD04541

\begin{tabular}{|c|c|c|c|c|c|c|c|c|c|c|c|}
\hline \multirow[t]{2}{*}{ Strain } & \multirow[t]{2}{*}{ Fragments } & \multicolumn{7}{|c|}{ Independent calli/fragment } & \multirow[t]{2}{*}{ Lines $^{b}$} & \multirow{2}{*}{$\begin{array}{c}\operatorname{ResBl}+ \\
\operatorname{nptII+}^{\mathrm{c}}(\%)\end{array}$} & \multirow{2}{*}{$\begin{array}{c}\operatorname{ResBl-}- \\
\text { nptII- }^{\mathrm{d}}(\%)\end{array}$} \\
\hline & & 0 & 1 & 2 & 3 & 4 & $\geq 5$ & Total $^{\mathrm{a}}$ & & & \\
\hline AGL1 & 254 & 107 & 46 & 49 & 42 & 9 & 1 & 311 & 200 & $121(60.5)$ & $79(39.5)$ \\
\hline LB4404 & 227 & 136 & 54 & 25 & 8 & 4 & 0 & 144 & 127 & $88(69.3)$ & $39(30.7)$ \\
\hline Total & 481 & 243 & 100 & 74 & 50 & 13 & 1 & 455 & 327 & $209(63.9)$ & $118(36.1)$ \\
\hline
\end{tabular}

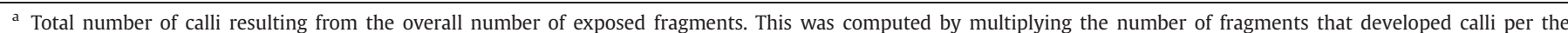
corresponding number of independent calli formed on each fragment.

$\mathrm{b}$ Indicates the number of independent shoots recovered from regenerating calli.

c Indicates presence of ResBl and nptII transgene as verified by PCR.

d Equates to absence of ResBl and nptII transgene. 


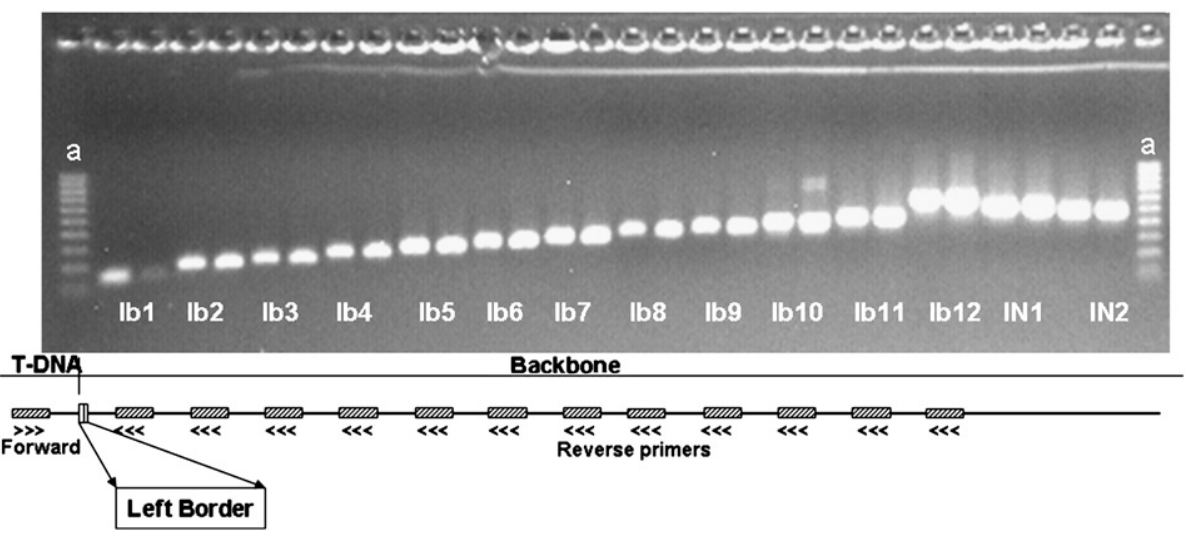

FIG. 3. Illustration of PCR based assay to verify lb1-lb12 and IN1, IN2 primers as completed in duplicate on two independent pCLDO4541 plasmids, a: 100 bp ladder.

sequence or the Ti plasmid encoded virD2 gene (data not shown). Of interest the AsBA indicated that 5 T-DNA negative lines (two-AGL1 and three-LBA4404-derived) were characterised by the presence of backbone sequence belonging to 4 major genes (Fig. 4) carried by the plasmid pCLDO4541, which also included the tetracycline antibiotic resistance gene. Integration rates for Tet, Tra, OriV and TrfA were calculated at $2.5 \%$ for the AGL1 lines and $7.7 \%$ for the LBA4404 lines, implying that an estimated $27 \mathrm{~kb}$ circa was integrated into the DNA of each individual.

PCR results were supported by Southern analysis (Fig. 5) with 2 AGL1 and one LBA4404-derived line containing a single backbone integration event. As expected, no hybridization signal was detected for the control non-Agrobacterium exposed Désireé line.

\section{DISCUSSION}

Since the first report of ATMT in potato $(29,30)$ numerous protocols have been published (40-44) aiming to improve the rate of transfor-

TABLE 3. Degree of vector backbone sequence integrated into transgenic potato following treatment via AGL1-based or LBA4404-based A. tumefaciens-mediated transformation

\begin{tabular}{llrc}
\hline Genotype & T-DNA border & ResBl-potato line ${ }^{\text {a }}$ & $\begin{array}{c}\text { Backbone sequence } \\
\text { length (bp) }\end{array}$ \\
\hline AGL1 & Left & $1-1$ & 621 \\
AGL1 & Left & $2-1$ & 454 \\
AGL1 & Left & $3-1$ & 454 \\
AGL1 & Left & $4-1$ & 621 \\
AGL1 & Left & $5-1$ & 424 \\
AGL1 & Left & $6-1$ & 621 \\
AGL1 & Left & $7-1$ & 621 \\
AGL1 & Left & $8-1$ & 621 \\
AGL1 & Right & $1-1$ & 539 \\
AGL1 & Right & $9-1$ & 539 \\
LBA 4404 & Left & $1-2$ & 621 \\
LBA 4404 & Left & $2-2$ & 621 \\
LBA 4404 & Left & $3-2$ & 621 \\
LBA 4404 & Left & $4-2$ & 454 \\
LBA 4404 & Left & $5-2$ & 454 \\
LBA 4404 & Left & $6-2$ & 621 \\
LBA 4404 & Left & $7-2$ & 621 \\
LBA 4404 & Left & $8-2$ & 621 \\
LBA 4404 & Right & $1-2$ & 539 \\
LBA 4404 & Right & $2-2$ & 539 \\
LBA 4404 & Right & $3-2$ & 539 \\
LBA 4404 & Right & $4-2$ & 539 \\
LBA 4404 & Right & $5-2$ & 539 \\
LBA 4404 & Right & $10-2$ & 539 \\
LBA 4404 & Right & $11-2$ & 539 \\
LBA 4404 & Right & $12-2$ & 539 \\
LBA 4404 & Right & 539 \\
\hline a S & &
\end{tabular}

a Same code number indicates the same plant line. mation, to reduce the genotype dependency and to eliminate the risk for somaclonal variation. Only relatively recently particle bombardment $(45,46)$ mediated transformation has been employed $(47,48)$. However, the use of the entire plasmid, in general favoured to the use of cassettes during particle bombardment, is often associated with complex concatamer integration patterns and the incorporation of backbone sequences, which complicate downstream risk assessments. Previous reports have noted how $A$. tumefaciens will integrate not only T-DNA sequences but also vector backbone sequences and this has been shown to occur adjacent to both borders of the T-DNA, with predominance for the left border $(49,50)$ even though the opposite was also reported (14). An initial assessment of potential backbone integration was done on 3 transgenic Karnico lines (32) and showed a complex pattern of repeat T-DNA and backbone sequence integration often separated by potato DNA. In this study we utilised a chromosome walking PCR-based approach to investigate not only the frequency of backbone integration on a large population of transgenic potato plants but also the extent of this erroneous sequence integration in relation to the bacterial strains utilised. Furthermore, we investigated the possibility that asynchronous sequence integration could occur resulting in A. tumefaciens delivering the plasmid backbone instead of the T-DNA in to the plant genome.

The initial transformation experiment employed 484 Désireé stem explants and two A. tumefaciens bacterial strains: AGL1 and LBA4404. As expected the number of independent calli regenerated following A. tumefaciens exposure was greater for the hypervirulent strain AGL1 (36) than for the LBA4404 (37) genotype. However, this manifested as a substantially higher number of independent transformed calli per treated fragment rather than an increase in the total number of fragments transformed $(p>0.05)$. An average transformation rate

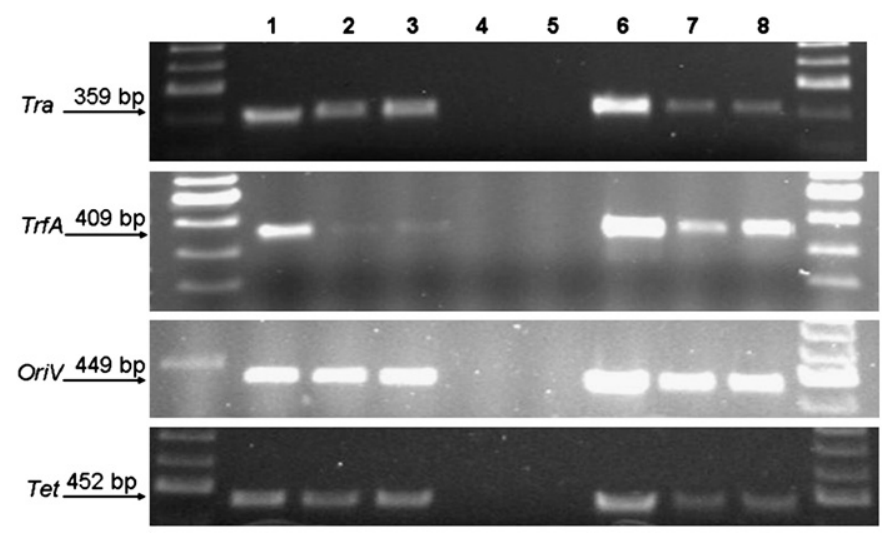

FIG. 4. Illustration of asynchronous backbone integration in the T-DNA negative lines 1, 2, 3, 7 and 8; 4: water, 5: untransformed plant and 6 vector pCLDO4541. 


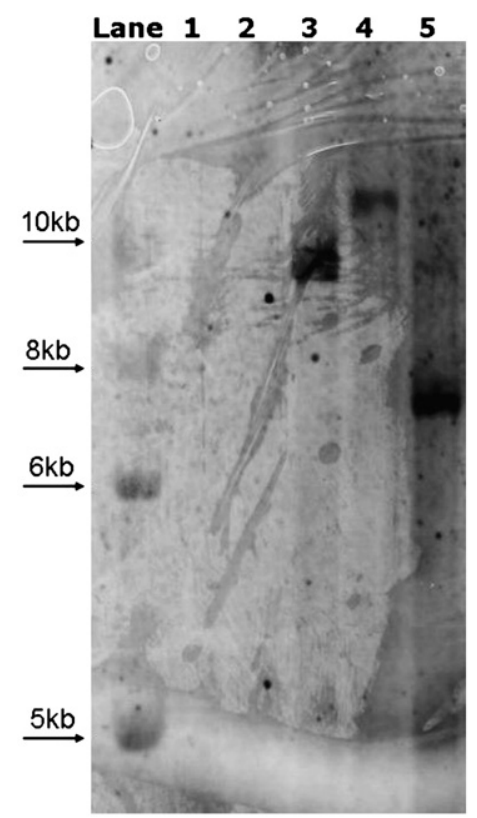

FIG. 5. Southern analysis indicating the stable integration of pCLDO4541 backbone sequence in T-DNA negative transgenic potato. Lane 1, water control; lane 2, untransformed potato; lanes 3, 4, AGL1 derived lines; lane 5, LBA4404 derived line.

was determined at $43.3 \%$ based on the PCR results. The application of a low selection pressure ( $\mathrm{kan}, 50 \mu \mathrm{g} / \mathrm{ml}$ ) reduced the toxicity of the selection increasing the recovery of transgenic plants but it also resulted in a substantial increment in the rate of false positive, or escapes (35\%, 118/327).

The genotype of the transforming bacterial strain clearly had an impact on potential backbone sequence integration. Remarkably, despite the higher virulence of the AGL1 strain, the overall rate of backbone integration accounted for just $8.2 \%$ of the transgenic ResBl potato population which was nearly half of the rate associated with the LBA4404-derived population (15\%). This trend was not only observed for the delivery and integration of backbone sequence at the right and left border of the T-DNA but was also recorded for the case of asynchronous delivery and integration of the full plasmid backbone sequences; $2.5 \%$ of AGL1 population against $7.7 \%$ of LBA4404-derived population. It seems evident that the genomic composition of the bacterial strain affects the way the vector borders are read and therefore what is in fact, being delivered. The importance of the left border as the T-strand terminator has already been reported in a study carried out on rice transformation (51) which showed that multiple repeats of the left border reduced the rate of backbone transformation. This is further supported through evidence that the left and the right borders can both act as initiator and terminator of T-strand production, where the most effective combination was the right-left and the less effective was the double pairing of the left.

In this study we showed that integration of the complete vector backbone occurred in 4.2\% (5/118) of the T-DNA negative lines, based on PCR analysis. This result is in accordance to what Gilbertons has shown with regards to the possibility of the LB and RB borders being able to act as initiator/terminator of T-DNA strand production (Gilbertons L., presented at the Symposium on Plant Transformation Technologies, Vienna, Austria, February 4-7, 2007). Hence, suggesting that errors in the recognition of the RB/LB borders can occur and the synthesis of the T-DNA takes place in the opposite (via backbone) direction. The LBA4404 strain was most prone to generate full backbone transformants. Indeed, Ramanathan et al. (15) generated tobacco calli resistant to kanamycin from a vector created with the nptII gene located outside the left border. In our system, no selection was applied to determine backbone transformed calli/plants. In fact, the intention was not to select for backbone transformed plants, rather to verify if non-transgenic plants or more accurately T-DNA negative plants could be harbouring vector DNA. As much as $27.6 \mathrm{~kb}$ of pCDLO4541 sequence was in fact delivered into the genome of 5 individual lines $(4.2 \%$ of untransformed population) which were morphologically identical to the wild type (data not shown). Preliminary analysis of these plants using interspersed-single sequence repeats (I-SSR), $(52,53)$ noted that the amplified DNA patterns were equivalent amongst transgenic lines and wild type (data not shown), indicating that no major genetic alterations had occurred following transformation with the backbone.

The possibility of utilising backbone transformed plants might have potential if the backbone is plant based; cisgenic $(54,55)$ or intragenic vector $(56,57)$ and the vector sequences at the left and right borders are regulatory elements for the introduced genes or matrix attachment regions (MARs). These sequences could greatly increase the efficiency by which transgenes are introduced and expressed, which could result in great benefit for those species, such as cereals, which are still difficult to transform for major traits.

The aim of this project was to investigate the potential genotype dependency of Agrobacterium in delivering non-T-DNA sequence into transgenic potato populations transformed for tolerance to P. infestans and to verify whether T-DNA negative plants could have been backbone transformed. Critically, this analysis forms part of the risk assessment required for these transgenic potato populations prior to their introduction into field trials to assess their tolerance to $P$. infestans (EC 2001/18). Significantly we have shown that LBA4404 was more prone to deliver backbone sequence either at the left or the right border compared to the more virulent strain, AGL1. Furthermore we proved the propensity for LBA4404 to facilitate full backbone integration (up to $27.6 \mathrm{~kb}$ ) more efficiently than AGL1. We also showed that a PCR based approach with chromosome walking is an effective system to identify backbone transformed plants. This information should be considered by the current cohort of scientist working on the development of disease resistant potato using the LBA4404 A. tumefaciens genotype.

\section{ACKNOWLEDGMENTS}

The authors wish to thank Dr. Kathrin Reiber for her critical review of the manuscript. Carloalberto Petti and Ewen Mullins were funded through the Irish National Development Plan (2000-2006).

\section{References}

1. An, G.: High efficiency transformation of cultured tobacco cells, Plant Physiol., 79, 568-570 (1985).

2. Baldes, R., Moos, M., and Geider, K.: Transformation of soybean protoplasts from permanent suspension-cultures by cocultivation with cells of Agrobacterium tumefaciens, Plant Mol. Biol., 9, (2) 135-145 (1987).

3. Bevan, M. W., Flavell, R. B., and Chilton, M. D.: A chimaeric antibiotic-resistance gene as a selectable marker for plant-cell transformation, Nature, 304, (5922) 184-187 (1983)

4. Fraley, R. T., Horsh, R. B., Matzke, A., Chilton, M. D., and Sanders, P. R.: In vitro transformation of Petunia cells by an improved method of co-cultivation with $A$. tumefaciens strains, Plant Mol. Biol., 3, (6) 371-378 (1984).

5. Tingay, S., McElroy, D., Kalla, R., Fieg, S., Wang, M. B., Thornton, S., and Brettell, R.: Agrobacterium tumefaciens-mediated barley transformation, Plant J., 11, (6) 1369-1376 (1997).

6. Gordonkamm, W. J., Spencer, T. M., Mangano, M. L., Adams, T. R., Daines, R. J., Start, W. G., Obrien, J. V., Chambers, S. A., Adams, W. R., and Willetts, N. G., et al.: Transformation of maize cells and regeneration of fertile transgenic plants, Plant Cell, 2, (7) 603-618 (1990).

7. Ishida, Y., Saito, H., Ohta, S., Hiei, Y., Komari, T., and Kumashiro, T.: High efficiency transformation of maize (Zea mays L) mediated by Agrobacterium tumefaciens, Nat. Biotechnol., 14, (6) 745-750 (1996).

8. Chan, M. T., Lee, T. M., and Chang, H. H.: Transformation of indica rice (Oryza sativa L) mediated by Agrobacterium tumefaciens, Plant and Cell Physiol., 33, (5) 577-583 (1992). 
9. Chan, M. T., Chang, H. H., Ho, S. L., Tong, W. F., and Yu, S. M.: Agrobacteriummediated production of transgenic rice plants expressing a chimeric alpha-amylase promoter beta-glucuronidase gene, Plant Mol. Biol., 22, (3) 491-506 (1993).

10. Hiei, Y., Ohta, S., Komari, T., and Kumashiro, T.: Efficient transformation of rice (Oryza sativa L) mediated by Agrobacterium and sequence-analysis of the boundaries of the T-DNA, Plant J., 6, (2) 271-282 (1994).

11. Koncz, C., Martini, N., Mayerhofer, R., Koncz-Kalman, Z., Korber, H., Redei, G. P., and Schell, J.: High-frequency T-DNA mediated gene tagging in plants, Pro. Natl. Acad. Sci. USA, 86, 8467-8471 (1989).

12. Herman, L., Jacobs, E., Van Montagu, M., and Depicker, A.: Plant chromosome/ marker gene fusion assay for study of normal and truncated T-DNA integration events, Mol. Gen. Genet., 224, 248-256 (1990).

13. Barakat, A., Gallois, P., Raynal, M., Mestre-Ortega, D., Sallaud, C., Guiderdoni, E., Delseny, M., and Bernardi, G.: The distribution of T-DNA in the genomes of transgenic Arabidopsis and rice, FEBS Lett., 471, 161-164 (2000).

14. Kononov, M. E., Bassuner, B., and Gelvin, S. B.: Integration of T-DNA binary vector backbone sequences into the tobacco genome: evidence for multiple complex pattern of integration, Plant J., 11, (5) 945-957 (1997).

15. Ramanathan, V. and Veluthambi, K.: Transfer of non-T-DNA portions of the Agrobacterium tumefaciens Ti plasmids pTiA6 from the left terminus of TL-DNA, Plant Mol. Biol., 28, 1149-1154 (1995).

16. Martineau, B., Voelker, T. A., and Sanders, R. A.: On defining T-DNA, Plant Cell, 6, 1032-1033 (1994)

17. Cellini, F., Chesson, A., Colquhoun, I., Constable, A., Davies, H. V., Engel, K. H., Gatehouse, A. M. R., Karenlampi, S., Kok, E. J., and Leguay, J.-J., et al.: Unintended effects and their detection in genetically modified crops, Food Chem. Toxicol., 42, 1089-1125 (2004).

18. Matzke, A. J. M. and Matzke, M. A.: Position effects and epigenetic silencing of plant transgenes, Curr. Opin. Plant Biol., 1, 142-148 (1998).

19. Matzke, M. A., Mette, M. F., and Matzke, A. J. M.: Transgene silencing by the host genome defense: implications for the evolution of epigenetic control mechanisms in plants and vertebrates, Plant Mol. Biol., 43, (2-3) 401-415 (2000).

20. Marvo, S. L., King, S. R., and Jaskunas, S. R.: Role of short regions of homology in intermolecular illegitimate recombination events, Proc. Natl. Acad. Sci. U.S.A., 80, (9) 2452-2456 (1983)

21. Tepfer, D., Garcia-Gonzales, R., Mansouri, H., Seruga, M., Message, B., Leach, F., and Perica, M. C.: Homology-dependent DNA transfer from plants to a soil bacterium under laboratory conditions: implications in evolution and horizontal gene transfer, Transgenic Res., 12, (4) 425-437 (2003).

22. Afolabi, A. S., Worland, B., Snape, J. W., and Vain, P.: A large-scale study of rice plants transformed with different T-DNAs provides new insights into locus composition and T-DNA linkage configurations, Theor. Appl. Genet., 109, 815-826 (2004).

23. Kim, S.-R., Lee, J., Jun, S.-H., Park, S. K., Kang, H.-G., Kwon, S., and An, G.: Transgene structures in T-DNA-inserted rice plants, Plant Mol. Biol., 52, 761-773 (2003).

24. Meza, T. J., Strageland, B., Mercy, I. S., Skarn, M., Nymoen, D. A., Berg, A., Butenko, M. A., Hakelien, A.-M., Haslekas, C., Meza-Zepeda, L. A., and Aalen, R. A.: Analyses of single-copy Arabidopsis T-DNA-transformed lines show that the presence of vector backbone sequences, short inverted repeats and DNA methylation is not sufficient or necessary for the induction of transgene silencing, Nucleic Acids Res., 30, (20) 4556-4566 (2002).

25. Abdal-Aziz, S. A., Pliego-Alfaro, F., Quesada, M. A., and Mercado, J. A.: Evidence of frequent integration of non-T-DNA vector backbone sequences in transgenic strawberry plant, J. Biosci. Bioeng., 101, (6) 508-510 (2006).

26. Maghuly, F., Khan, M. A., Fernandez, E. B., Druart, F., Watillon, B., and Laimer, M.: Stress regulated expression of the GUS-marker gene (uidA) under the control of plant calmodulin and viral 35S promoters in a model fruit tree rootstock: Prunus incisa $\times$ serrula, J. Biotechnol., 135, 105-116 (2008).

27. Lange, M., Vincze, E., Moller, M. J., and Holm, P. B.: Molecular analysis of transgene and vector backbone integration into the barley genome following Agrobacteriummediated transformation, Plant Cell Rep., 25, 815-820 (2006).

28. Mullins, E., Milbourne, D., Petti, C., Doyle-Prestwich, B. M., and Meade, C.: Potato in the age of biotechnology, Trends Plant Sci., 11, (5) 254-260 (2006).

29. An, G., Watson, B. D., and Chiang, C. C.: Transformation of tobacco, tomato, potato and Arabidopsis thaliana using a binary Ti vector system, Plant Physiol., 81, 301-305 (1986).

30. Shahin, E. A. and Simpson, R. B.: Gene transfer system for potato, HortScience, 21, (5) 1199-1201 (1986).

31. Andersson, M., Melander, M., Pojmark, P., Larsson, H., Bulow, L., and Hofvander, P.: Targeted gene suppression by RNA interference: an efficient method for production of high-amylose potato lines, J. Biotechnol., 123, 137-148 (2006)

32. Wolters, A.-M., Trindale, L. M., Jacobsen, E., and Visser, R. G. V.: Fluorescence in situ hybridization on extended DNA fibres as a tool to analyse complex T-DNA loci in potato, Plant J., 13, (6) 837-847 (1998).

33. Song, J., Bradeen, J. M., Naess, S. K., Raash, J. A., Wielgus, S. M., Haberlach, G. T., Liu, J., Kuang, H., Austin-Phillips, S., Buell, C. R., Helgeson, J. P., and Jiang, J.: Gene
$R B$ cloned from Solanum bulbocastanum confers broad spectrum resistance to potato late blight, Proc. Natl. Acad. Sci. U.S.A., 100, (16) 9128-9133 (2003).

34. Van der Vossen, E., Sikkema, A., Hellert, B. L., Gros, J., Stevens, P., Muskens, M., Wouters, D., Pereira, A., Stiekema, W., and Allefs, S.: An ancient R gene from the wild potato species Solanum bulbocastanum confers broad-spectrum resistance to Phytophthora infestans in cultivated potato and tomato, Plant J., 36, (6) 867-882 (2003).

35. Jones, J. D. G., Shlumukov, L., Carland, F., Enhlish, J., Scofield, S. R., Bishop, G. J. and Harrison, K.: Effective vectors for transformation, expression of heterologous genes, and assaying transposon excision in transgenic plants, Transgenic Res., 1, (6) 285-297 (1992)

36. Lazo, G. R., Stein, P. A., and Ludwig, R. A.: A DNA transformation-competent Arabidopsis genomic library in Agrobacterium, Biotechnology (N.Y.), 9, 963-967 (1991).

37. Hoekema, A., Hirsch, P. R., Hooykaas, P. J. J., and Schilperoort, R. E.: A binary plant vector strategy based on separation of vir-and T-region of the Agrobacterium tumefaciens Ti-plasmid, Nature, 303, 179-180 (1983).

38. Höfgen, R. and Willmitzer, L.: Storage of competent cells for Agrobacterium transformation, Nucleic Acids Res., 16, (20) 9877 (1988).

39. Millett, B. P. and Bradeen, J. M.: Development of allele-specific PCR and RT-PCR assays for clustered resistance genes using a potato late blight resistance transgene as a model, Theor. Appl. Genet., 114, 501-513 (2007).

40. Sherman, S. and Bevan, M. W.: A rapid transformation method for Solanum tuberosum using binary Agrobacterium tumefaciens, Plant Cell Rep., 7, 13-16 (1988).

41. Hulme, J. S., Higgins, E. S., and Shields, R.: An efficient genotype-independent method for regeneration of potato plants from leaf tissue, Plant Cell Tissue Organ Cult., 31, 161-167 (1992).

42. Ishida, B. K., Snyder Jr., G. W., Jr., and Belknap, W. R.: The use of in vitro-grown microtubers discs in Agrobacterium-mediated transformation of Russet Burbank and Lemhi Russet potatoes, Plant Cell Rep., 8, 325-328 (1989).

43. Block, M. D.: Genotype-independent leaf disc transformation of potato (Solanum tuberosum) using Agrobacterium tumefaciens, Theor Appl Genet, 76, 767-774 (1988).

44. Beaujean, A., Sangwan, R. S., Lecardonnel, A., and Sangwan-Nooreel, B. S. Agrobacterium-mediated transformation of three economically important potato cultivars using sliced internodal explants: an efficient protocol of transformation, J. Exp. Bot., 49, (326) 1589-1595 (1998).

45. Klein, T. M., Wolf, E. D., Wu, R., and Sanford, J. C.: High-velocity microprojectiles for delivering nucleic acids into living cells, Nature, 327, 70-73 (1987).

46. Sanford, J. C., Klein, T. M., Wolf, E. D., and Allen, N.: Delivery of substances into cells and tissues using a particle bombardment process, J. Part. Sci. Technol., 5, 27-37 (1987)

47. Romano, A., Raemakers, K., Bernardi, J., Visser, R., and Mooibroek, H.: Transgene organisation in potato after particle bombardment-mediated (co-)transformation using plasmids and gene cassettes, Transgenic Res., 12, (4) 461-473 (2003).

48. Romano, A., Raemakers, K., Visser, R., and Mooibroek, H.: Transformation of potato (Solanum tuberosum) using particle bombardment, Plant Cell Rep., 20, (3) 198-204 (2001).

49. De Buck, S., De Wilde, C., Van Montagu, M., and Depicker, A.: T-DNA vector backbone sequences are frequently integrated into the genome of transgenic plants obtained by Agrobacterium-mediated transformation, Mol. Breed., 6, 459-468 (2000)

50. Meng, Y., Patrel, G., Heist, M., Betts, M. F., Tucker, S. L., Galadima, N., Donofrio, N. M., Brown, D., Mitchell, T. K., and Li, L., et al.: A systemic analysis of T-DNA insertion events in Magnaporthe oryzae, Fungal Genet. Biol., 44, (10) 1050-1064 (2007).

51. Kuraya, Y., Otha, S., and Fuduka, M.: Suppression of transfer of non-t-DNA 'Vector backbone' sequences by multiple left borders repeats in vectors for transformation of higher plants mediated by Agrobacterium tumefaciens, Mol. Breed., 14, 309-320 (2004).

52. Albani, M. C. and Wilkinson, M. J.: Inter ample sequence repeat polymerase chain reaction for the detection of somaclonal variation, Plant Breed., 117, 573-575 (1998).

53. Thomas, J., Vijayan, D., Joshi, S. D., Lopez, S. J., and Kumar, R. R.: Genetic integrity of somaclonal variants in tea (Camellia sinensis (L.) O Kuntze) as revealed by inter simple sequence repeats, J. Biotechnol., 1233, (2) 149-154 (2006).

54. Schouten, H. J. and Jacobsen, E.: Cisgenesis and intragenesis, sisters in innovative plant breeding, Trends Plant Sci., 13, (6) 260-261 (2008).

55. Jacobsen, E. and Schouten, H. J.: Cisgenesis strongly improves introgression breeding and induced translocation breeding of plants, Trends Biotechnol., 25, 219-233 (2007)

56. Barrell, P. J. and Conner, A. J.: Minimal T-DNA vectors suitable for agricultural deployment of transgenic plants, BioTechniques, 41, 708-710 (2006).

57. Conner, A. J., Barrel, P. J., Baldwin, S. J., Lokerse, A. S., Cooper, P. A., Erasmuson, A. K., Nap, J. A., and Jacobs, J. M. E.: Intragenic vectors for gene transfer without foreign DNA, Euphytica, 154, 341-353 (2007). 